\title{
Membangun Web Server Menggunakan Debian Server Sebagai Pendukung Media Pembelajaran Di SMA Negeri 1 Baros
}

\author{
Saleh Dwiyatno ${ }^{1}$, Wiwin Susilawati ${ }^{2}$ \\ ${ }^{1}$ Program Studi Sistem Komputer Fakutas Teknologi Informasi Universitas Serang Raya \\ ${ }^{2}$ Program Studi Sistem Komputer Fakutas Teknologi Informasi Universitas Serang Raya \\ Jln. Raya Cilegon Serang - Drangong Kota Serang \\ ${ }^{1}$ salehdwiyatno@gmail.com \\ wiwinsusilawati@gmail.com
}

\begin{abstract}
Perkembangan teknologi yang semakin maju mempengaruhi suatu sistem dan efisiensi operasional dalam dunia pendidikan yang menggunakan fasilitas jaringan internet untuk mendukung proses belajar mengajar. Dengan memanfaatkan jaringan komputer dan fasilitas internet, guru dan siswa dapat mencari referensi pembelajaran dan kemudahan komunikasi demi mendukung proses pembelajaran. Penelitian ini bertujuan untuk menghasilkan web server pada SMA Negeri 1 Baros sebagai website pembelajaran siswa. Penelitian ini bermanfaat untuk meningkatkan pembelajaran siswa yang di dukung dengan media website serta mengetahui cara teknik implementasi suatu jaringan client-server di SMA Negeri 1 Baros. Dalam perancangan dan pembangunan web server ini penulis menggunakan debian. Hasil dari penelitian ini adalah jaringan yang semakin optimal dengan web server sebagai media pembelajaran sehingga siswa dapat mengakses, mengunduh materi dan mengerjakan soal secara online.
\end{abstract}

Kata kunci: Web server, Debian, Media Pembelajaran, On-line, website.

\section{PENDAHULUAN}

Seiring dengan perkembangan teknologi yang semakin maju mempengaruhi suatu sistem dan efisiensi operasional dalam dunia pendidikan yang menggunakan fasilitas jaringan komputer dan internet untuk mendukung proses belajar mengajar. Perkembangan jaringan internet pun cukup banyak mengalami banyak kemajuan, hal ini membuat kita untuk berupaya meningkatkan kemampuan dan mengoptimalkan sumber daya perangkat keras dan perangkat lunak dalam mengakses internet. Dengan memanfaatkan jaringan komputer dan fasilitas internet, guru dan siswa dapat mencari referensi pembelajaran dan kemudahan komunikasi demi mendukung proses pembelajaran. Di Sekolah Menengah Atas (SMA) Negeri 1 Baros memang sudah memiliki fasilitas laboratorium komputer, dan masing-masing sudah terhubung dalam satu jaringan komputer. Untuk meningkatkan proses pembelajaran siswa bahkan pengajar, khususnya dalam teknologi informasi maka dibutuhkan server jaringan komputer yang memungkinkan dapat menyediakan layanan web tertentu bagi client atau pengguna. Oleh karena itu perlu adanya pembangunan web server di SMA Negeri 1 Baros sebagai media intranet maupun internet untuk meningkatkan proses pembelajaran siswa.

Dalam latar belakang yang telah dikemukakan di atas maka terdapat beberapa hal yang teridentifikasi, yaitu:
1. Belum adanya fasilitas web server di SMA Negeri 1 Baros.

2. Belum memiliki fasilitas debian server sebagai pendukung jaringan web server yang ada di SMA Negeri 1 Baros.

3. Topologi belum optimal karena masih menggunakan topologi star sehinga masih belum maksimal dalam menunjang pemakaian internet.

Berdasarkan identifikasi di atas maka penelitian ini akan meneliti tentang cara mengimplementasikan sistem jaringan Client Server di SMA Negeri 1 Baros dan pembangunan web server menggunakan debian server sebagai pendukung media pembelajaran siswa serta meneliti sistem apa saja yang digunakan untuk membangun web server dengan menggunakan debian server sebagai pendukung media pembelajaran di SMA Negeri 1 Baros.

\section{METODE PENELITIAN}

Pada penelitian ini menggunakan metode Penelitian Historis yang bertujuan untuk membuat rekonstruksi masa lampau secara sistematis dan obyektif. 


\section{HASIL DAN PEMBAHASAN}

\subsection{Manajemen Jaringan Usulan \\ Topologi Jaringan}

Untuk dapat mengimplementasikan teknologi jaringan nirkabel $(\mathrm{Wi}-\mathrm{Fi})$, terlebih dahulu harus dipahami tentang arsitektur dasarnya dan sesuai dengan perencanaan yang telah digambarkan di BAB III yang pada kenyataannya sangat tergantung dilapangan (SMA Negeri 1 Baros) dan sangat potensial akan keberhasilan pada implementasi teknologi $\mathrm{Wi}$-Fi tersebut, terutama pada kekuatan sinyal dan jarak jangkauan (hotspot area) khususnya dalam akses free internet hotspot.

Disini penulis ingin menggambarkan topologi jaringan dengan menggunakan $W i-F i$.

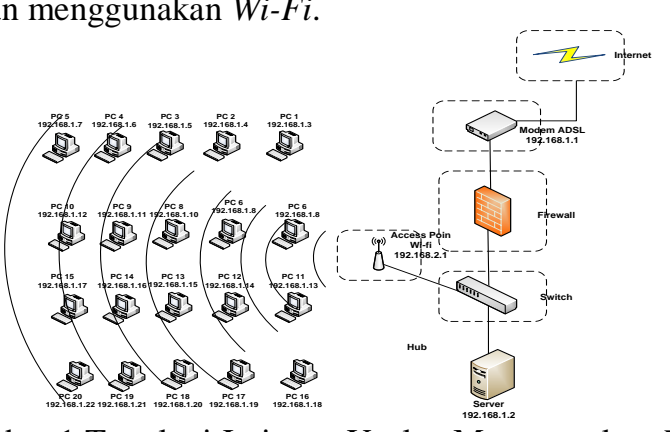

Gambar 1 Topologi Jaringan Usulan Menggunakan Wi-Fi

\section{Skema Jaringan}

Berisi tentang gambar rangkaian jaringan komputer pada obyek penelitian dan spesifikasi jaringan komputer yang ada pada obyek penelitian secara detail (gambar skema jaringan dapat berasal dari perusahaan atau dibuat menggunakan aplikasi visio atau aplikasi sejenis), dengan menggunakan skema jaringan usulan $\mathrm{Wi}-\mathrm{Fi}$ penggunaan $h u b$ dapat dikurangi, efisien dan lebih cepat.

Dibawah ini adalah skema jaringan Usulan di SMA Negeri 1 Baros :

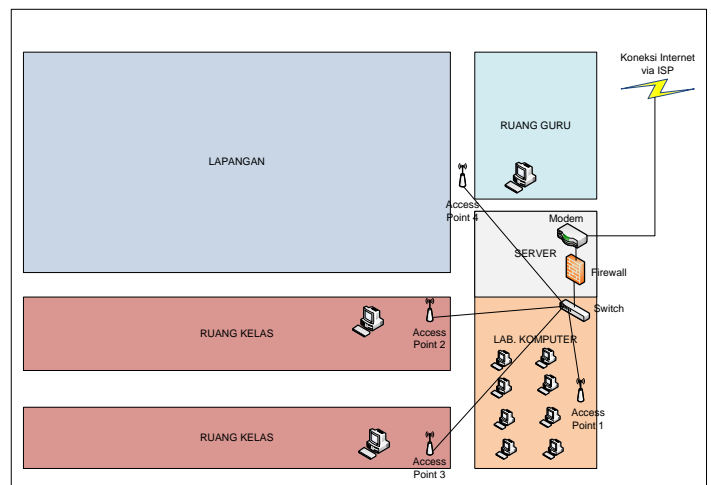

Gambar 2 Skema Jaringan Usulan SMA Negeri 1 Baros

\section{Keamanan Jaringan}

Spesifikasi IEEE 802.11 menunjukkan beberapa layanan yang menyediakan lingkungan operasi yang aman. Layanan keamanan disediakan sebagian besar oleh protocol Wired Equivalent Privacy (WEP) untuk melindungi link level data selama transmisi wireless antara client dan access point. WEP tidak menyediakan keamanan end-to-end, tapi hanya untuk bagian wireless dari koneksi seperti ditunjukkan pada gambar di bawah ini.

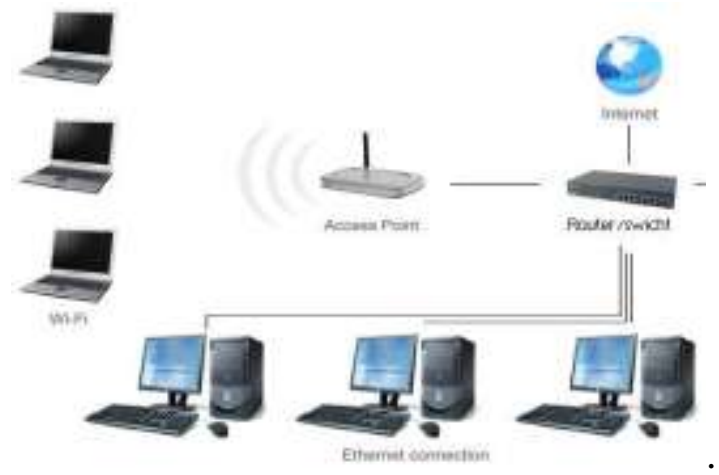

Gambar 3 Sistem Keamanan Wi-fi 802.11

\section{Fitur Keamanan Wi-Fi 802.11}

Tiga layanan kemanan dasar yang ditentukan oleh IEEE untuk lingkungan WLAN (Wi-Fi Hotspot) adalah sebagai berikut :

1. Otentifikasi. Tujuan utama dari WEP adalah menyediakan layanan keamanan untuk memastikan identitas lokasi client yang berkomunikasi. Ini menyediakan kontrol bagi jaringan dengan menolak akses ke stasion client yang tidak dapat memberikan otentifikasi secara benar.

2. Kerahasiaan. Kerahasiaan, atau privasi, adalah tujuan kedua WEP. Ini dibuat untuk menyediakan "privasi yang diperoleh pada jaringan kabel.” Maksudnya adalah untuk mencegah bocornya informasi dengan cara serangan pasif.

3. Integritas. Tujuan lain dari WEP adalah layanan keamanan yang dibuat untuk memastikan bahwa pesan tidak dirubah sewaktu pengiriman antara client wireless dan access point dalam serangan aktif.

Pengujian Jaringan Awal

Setelah melakukan instalasi dan konfigurasi Web Server saat nya menguji Web server dengan mengkonfigurasi dan mengaktifkan web media pembelajaran. Membuat konfigurasi domain, agar web media pembelajaran yang ada di debian server dapat diakses oleh seluruh komputer client, berikut adalah konfigurasi domain web server di debian server 7.

Tabel 1 Pengujian Jaringan Awal Menggunakan Lan di SMAN 1 Baros

\begin{tabular}{clccc}
\hline No & Pengujian & Status & Kecepatan & Keterangan \\
\hline 1 & Transfer Rate & Baik & $50 \mathrm{Mbps}$ & \\
2 & Upload & Baik & $10 \mathrm{Mbps}$ & \\
3 & Download & Baik & $100 \mathrm{Mbps}$ & \\
4 & Jangkauan Jaringan & Buruk & - & Tidak ada jangakauan \\
& sampai > 20 Meter & & & kabel sampai lebih \\
& & & & dari 20 Meter
\end{tabular}

Tabel 2 Pengujian Jaringan Awal Kecepatan Jaringan Web Server dengan LAN

\begin{tabular}{ll|ccc}
\hline \multirow{2}{*}{ No } & OS & \multicolumn{2}{l}{ Proses Running } & Kurasi \\
\cline { 3 - 4 } & $\begin{array}{l}\text { Berh Gagal } \\
\text { asil }\end{array}$ & Ket \\
\hline 1 & Debian Server & $\sqrt{ }$ & 0.20 & \\
& Windows 7 & $\sqrt{ }$ & 2.0 & \\
\hline
\end{tabular}




\begin{tabular}{|c|c|c|c|c|c|}
\hline \multirow[b]{2}{*}{ No } & \multirow[b]{2}{*}{ OS } & \multicolumn{2}{|c|}{ Proses Running } & \multirow[b]{2}{*}{$\begin{array}{l}\text { Durasi } \\
\text { (Detik) }\end{array}$} & \multirow[b]{2}{*}{ Ket } \\
\hline & & $\begin{array}{l}\text { Berh } \\
\text { asil }\end{array}$ & Gagal & & \\
\hline 3 & $\begin{array}{l}\text { Windows } \\
\text { Server } 2003\end{array}$ & & $\sqrt{ }$ & 0.00 & $\begin{array}{l}\text { Error, Web Server } \\
\text { Not Support }\end{array}$ \\
\hline 4 & $\begin{array}{l}\text { Windows } \\
\text { Server } 2008\end{array}$ & $\sqrt{ }$ & & 1.90 & \\
\hline
\end{tabular}

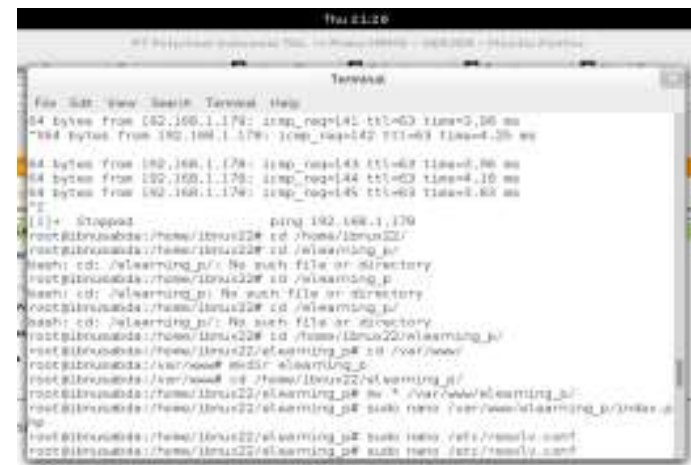

Gambar 4 Setting Dns Web Server

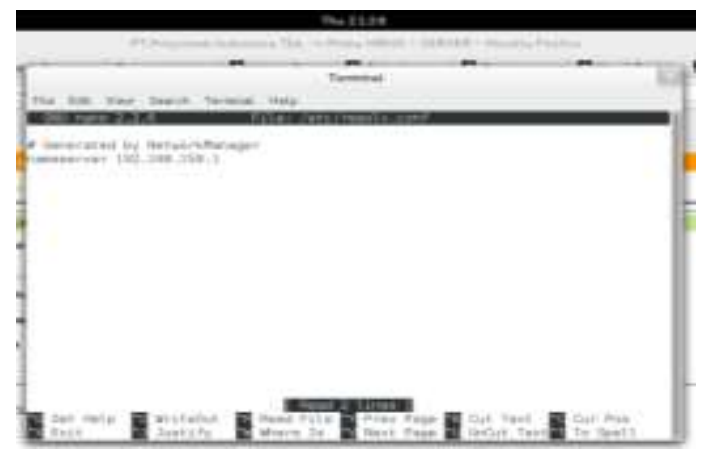

Gambar 5 Setting IP Web Server

Setelah Domain selesai dibuat langkah selanjutnya adalah membuat file e-learning_p di direktori /var/www/ seperti gambar dibawah.

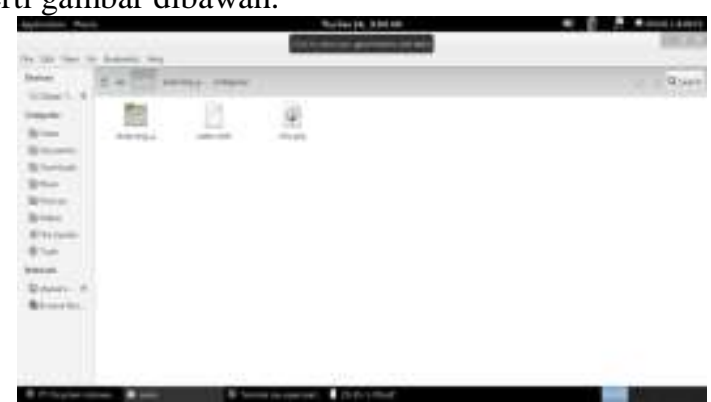

Gambar 6 Direktori Media Pembelajaran SMA N 1 Baros

Setelah selesai buka halaman http://localhost/phpmya dmin, login dengan username root dan password root. Buat database baru dengan nama elearning_p, kemudian import database dari direktori /var/www/elearning_p/, setelah itu klik tombol go. Database berhasil dibuat.

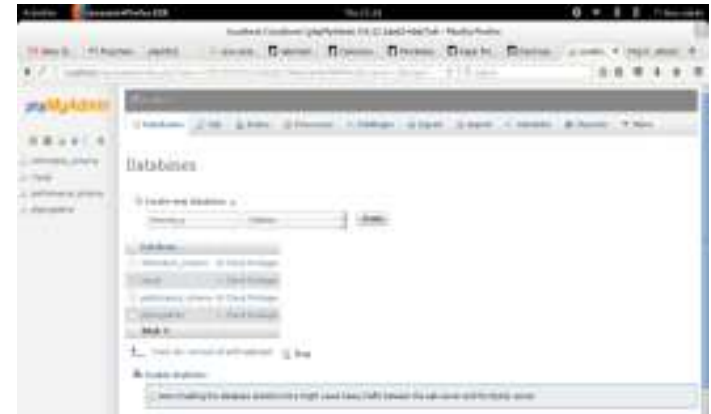

Gambar 7 Create Database Elearning

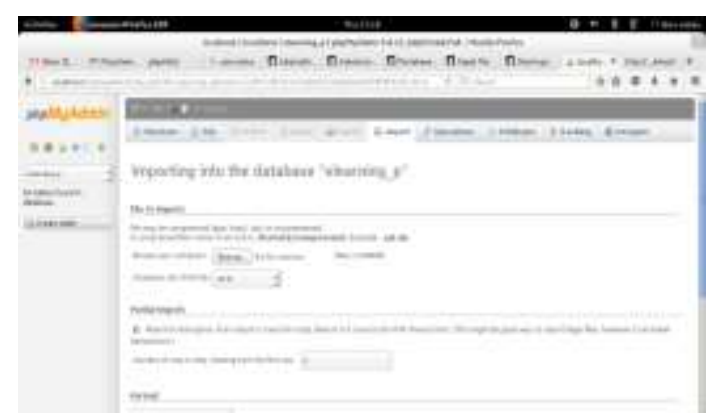

Gambar 8 Import file sql ke database

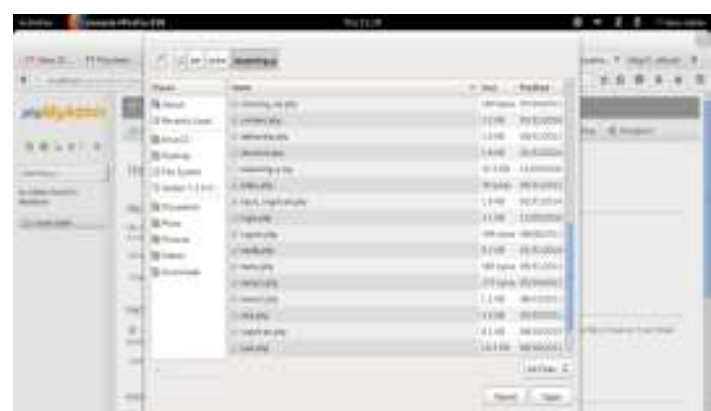

Gambar 9 Mengambil file sql dari direktori

Setelah semua konfigurasi selesai, langkah selanjutnya adalah mengetes web media pembelajaran lewat komputer client dengan mengetikkan http://sman1baros.elearning.sch.id di komputer client, jika tampilannya seperti di bawah ini, berarti instalasi dan konfigurasi web server telah berhasil dibuat.

\section{Pengujian Jaringan Akhir}

Pengujian akhir jaringan, web server dan aplikasi pembelajaran e-learning pada SMA Negeri 1 Baros ini terdiri dari beberapa form yang memiliki fungsi sendirisendiri. Form-form tersebut akan tampil secara berurutan sesuai dengan aturan yang telah terprogram, setelah pengguna melakukan proses tertentu.

Tabel 3 Pengujian Jaringan Akhir Menggunakan Wifi di

\begin{tabular}{clccc}
\multicolumn{5}{c}{ SMAN 1 Baros } \\
\hline No & Pengujian & Status & Kecepatan & Ket \\
\hline 1 & Transfer Rate & Baik & $100 \mathrm{Mbps}$ & \\
2 & Upload & Baik & $40 \mathrm{Mbps}$ & \\
3 & Download & Baik & $150 \mathrm{Mbps}$ & \\
4 & Jangkauan Jaringan sampai & Sangat & - & Strength \\
& $>$ 20 Meter & Baik & & Signal \\
\hline
\end{tabular}


Tabel 4 Data Pengujian Kecepatan dalam menjalankan Web

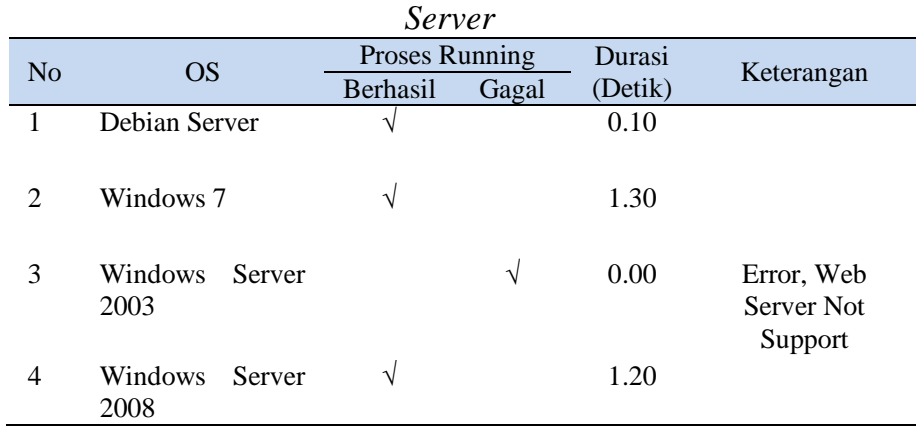

Halaman Login Siswa

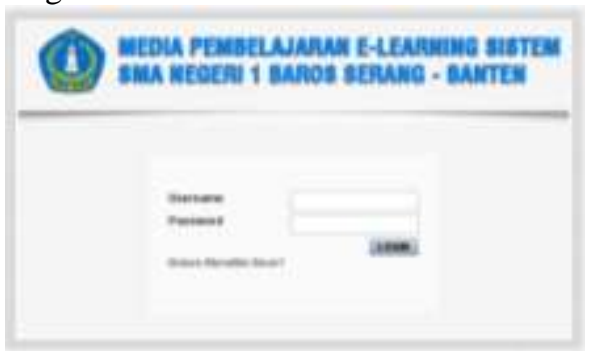

Gambar 10 Halaman Login Siswa

Tabel 5 Deskripsi Halaman Login

\begin{tabular}{|c|c|}
\hline $\begin{array}{c}\text { Keterangan } \\
\text { Layar }\end{array}$ & Halaman Login \\
\hline Aktor & Siswa \\
\hline Deskripsi & $\begin{array}{l}\text { Siswa masuk ke halaman login, lalu memasukkan } \\
\text { username dan password, jika cocok data akan divalidasi } \\
\text { dan masuk ke menu utama/dashboard media } \\
\text { pembelajaran. }\end{array}$ \\
\hline
\end{tabular}

\section{Halaman Login}

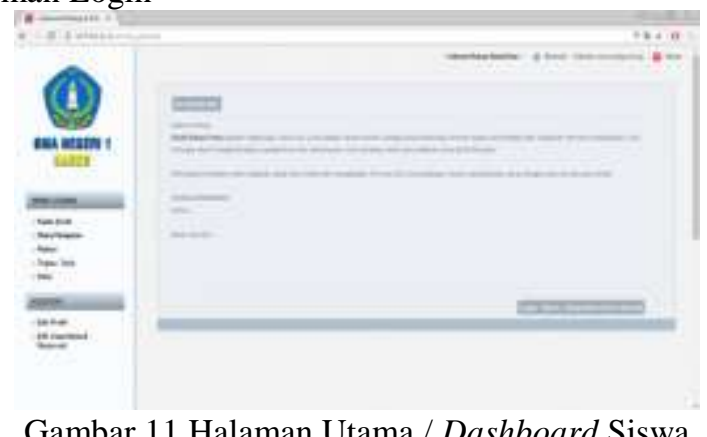

Tabel 6 Deskripsi Halaman Utama / Dashboard Siswa

\begin{tabular}{ll}
$\begin{array}{c}\text { Keterangan } \\
\text { Layar }\end{array}$ & \multicolumn{1}{c}{ Halaman Utama / Dashboard Siswa } \\
\hline Aktor & Siswa \\
Deskripsi & Siswa login, lalu memasukkan username dan password, \\
& jika cocok data akan divalidasi dan masuk ke menu \\
& utama / Dashboard siswa. \\
\hline
\end{tabular}

Informasi Kelas Siswa

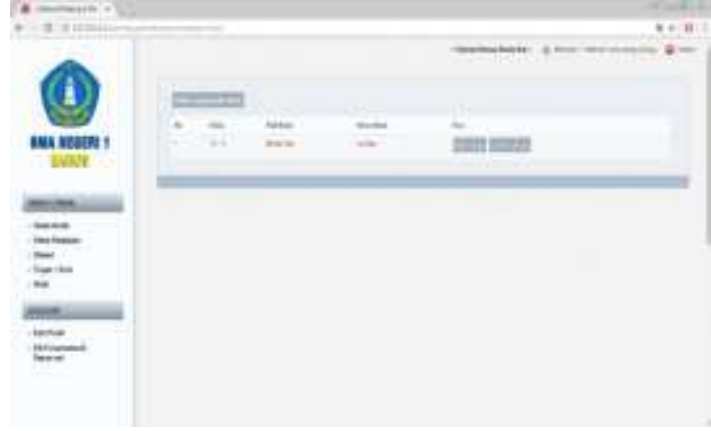

Gambar 12 Informasi Kelas Siswa

Tabel 7 Deskripsi Informasi Akses Jalan

\begin{tabular}{|c|c|}
\hline $\begin{array}{c}\text { Keterangan } \\
\text { Layar }\end{array}$ & Informasi Kelas Siswa \\
\hline Aktor & Siswa \\
\hline Deskripsi & $\begin{array}{l}\text { siswa membuka web. Pilih menu Kelas Anda maka sistem } \\
\text { akan menampilkan informasi yang dipilih secara } \\
\text { keseluruhan, siswa bisa melihat informasi kelas, edit kelas } \\
\text { dan lihat teman satu kelas. }\end{array}$ \\
\hline
\end{tabular}

\section{Informasi Mata Pelajaran}

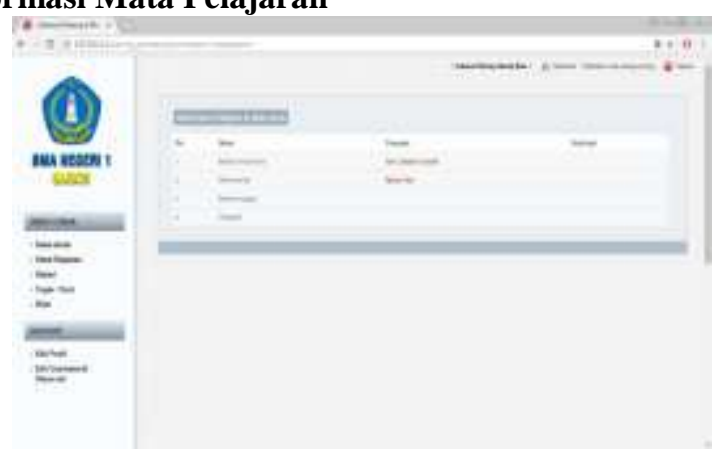

Gambar 13 Mata Pelajaran

Tabel 8 Mata Pelajaran

\begin{tabular}{ll}
\hline $\begin{array}{c}\text { Keterangan } \\
\text { Layar }\end{array}$ & \multicolumn{1}{c}{ Mata Pelajaran } \\
\hline Aktor & Siswa \\
Deskripsi & $\begin{array}{l}\text { Siswa membuka website. Setelah itu, Pilih menu mata } \\
\text { pelajaran maka sistem akan menampilkan list data mata } \\
\text { pelajaran beserta guru pengajar. }\end{array}$ \\
\hline
\end{tabular}

\section{Melihat Materi Pelajaran}

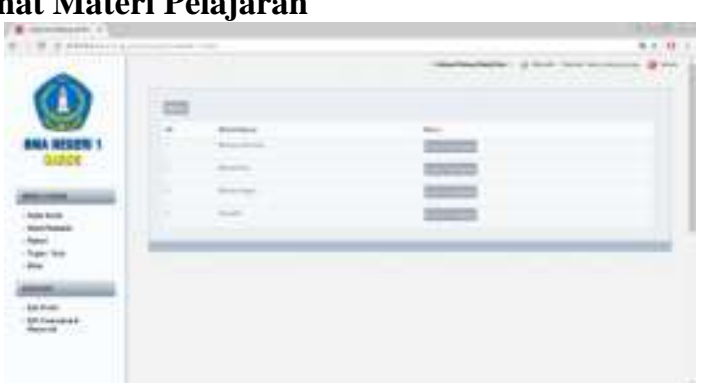

Gambar 14 Melihat Materi Pelajaran

Tabel 9 Deskripsi Melihat Materi Pelajaran

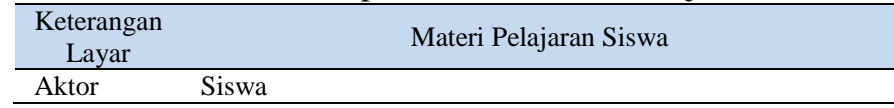




\begin{tabular}{cl}
\hline $\begin{array}{c}\text { Keterangan } \\
\text { Layar }\end{array}$ & \multicolumn{2}{c}{ Materi Pelajaran Siswa } \\
\hline Deskripsi & $\begin{array}{l}\text { Siswa masuk ke halaman login, lalu memasukkan } \\
\text { username dan password, jika cocok data akan divalidasi } \\
\text { dan masuk ke menu utama. Pilih menu Materi, maka } \\
\text { akan muncul table data Materi. }\end{array}$ \\
\hline
\end{tabular}

\section{Data Tugas / Quiz}

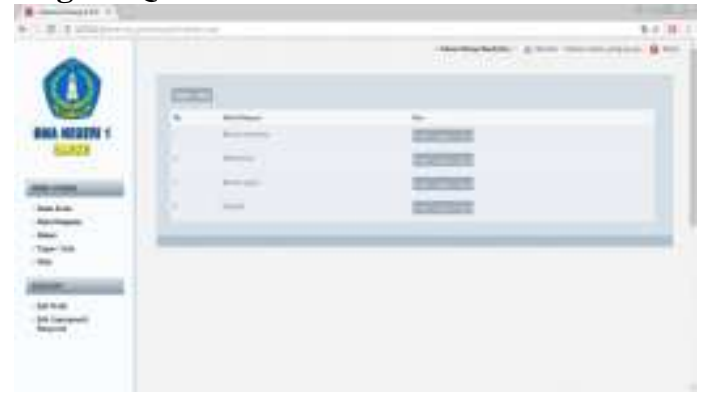

Gambar 15 Data Tugas / Quiz

Tabel 10 Deskripsi Data Tugas / Quiz

\begin{tabular}{ll}
\hline $\begin{array}{l}\text { Keterangan } \\
\text { Layar }\end{array}$ & \multicolumn{1}{c}{ Data Tugas / Quiz } \\
\hline Aktor & Siswa \\
Deskripsi & $\begin{array}{l}\text { Siswa masuk ke halaman login, lalu memasukkan } \\
\text { username dan password, jika cocok data akan divalidasi } \\
\text { dan masuk ke menu utama. Pilih menu Tugas / quiz dan } \\
\text { akan muncul Data tugas / quiz dan siswa bisa mengerjakan } \\
\text { tugas / quiz }\end{array}$ \\
\hline
\end{tabular}

\section{Melihat Nilai}

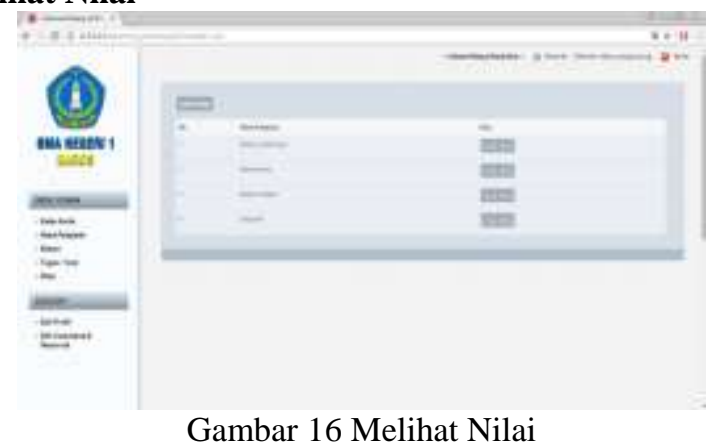

Tabel 11 Melihat Nilai

\begin{tabular}{ll}
$\begin{array}{c}\text { Keterangan } \\
\text { Layar }\end{array}$ & \multicolumn{1}{c}{ Melihat Nilai } \\
\hline Aktor & Siswa \\
Deskripsi & siswa masuk ke halaman login, lalu memasukkan \\
& $\begin{array}{l}\text { username dan password, jika cocok data akan divalidasi } \\
\text { dan masuk ke menu utama. Pilih menu data nilai dan } \\
\\
\text { akan muncul tabel data nilai tugas/quiz. }\end{array}$ \\
\hline
\end{tabular}

\section{Login Admin}

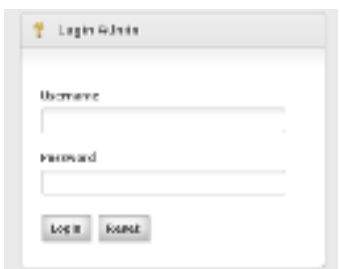

Gambar 17 Login Guru
Tabel 12 Deskripsi Login Guru

\begin{tabular}{ll}
\hline $\begin{array}{c}\text { Keterangan } \\
\text { Layar }\end{array}$ & \multicolumn{2}{c}{ Login Guru } \\
\hline Aktor & Guru \\
Deskripsi & $\begin{array}{l}\text { Guru masuk ke halaman login, lalu memasukkan } \\
\text { username dan password, jika cocok data akan divalidasi } \\
\text { dan masuk ke menu utama. }\end{array}$ \\
\hline
\end{tabular}

\section{Halaman Utama Guru}

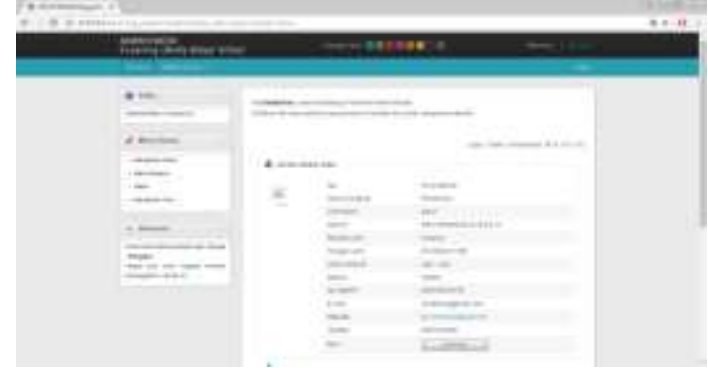

Gambar 18 Halaman Utama Guru

Tabel 13 Halaman Utama Guru

\begin{tabular}{ll}
\hline $\begin{array}{c}\text { Keterangan } \\
\text { Layar }\end{array}$ & \multicolumn{3}{c}{ Halaman Utama Guru } \\
\hline Aktor & Guru \\
Deskripsi & $\begin{array}{l}\text { Guru masuk ke halaman login, lalu memasukkan } \\
\text { username dan password, jika cocok data akan divalidasi } \\
\text { dan masuk ke menu utama. }\end{array}$ \\
\hline
\end{tabular}

\subsection{Analisis dan Rancangan Aplikasi}

Konsep dasar penyelesaian dengan membuat sistem yang menggunkan web. Program aplikasi yang akan dibuat adalah Sistem Media Pembelajaran Pada SMAN 1 Baros Berikut adalah perancangan masukan, perancangan keluaran dan perancangan proses sistem pendukung dengan urutan proses atau prosedur dari masing-masing kegiatan tersebut.

Use Case E-Learning Pembelajaran Siswa Pada SMAN Negeri 1 Baros

Perancangan prosedur yang di usulkan akan berorientasi objek dengan menggunakan notasi UML yang berfungsi sebagai alat dokumentasi dan visualisasi. Pada sistem ini hanya terdapat dua jenis user yang mengakses kedalam sistem, kedua user ini mempunyai ruang lingkup akses yang berbeda-beda. Kedua jenis user ini didefinisikan : 


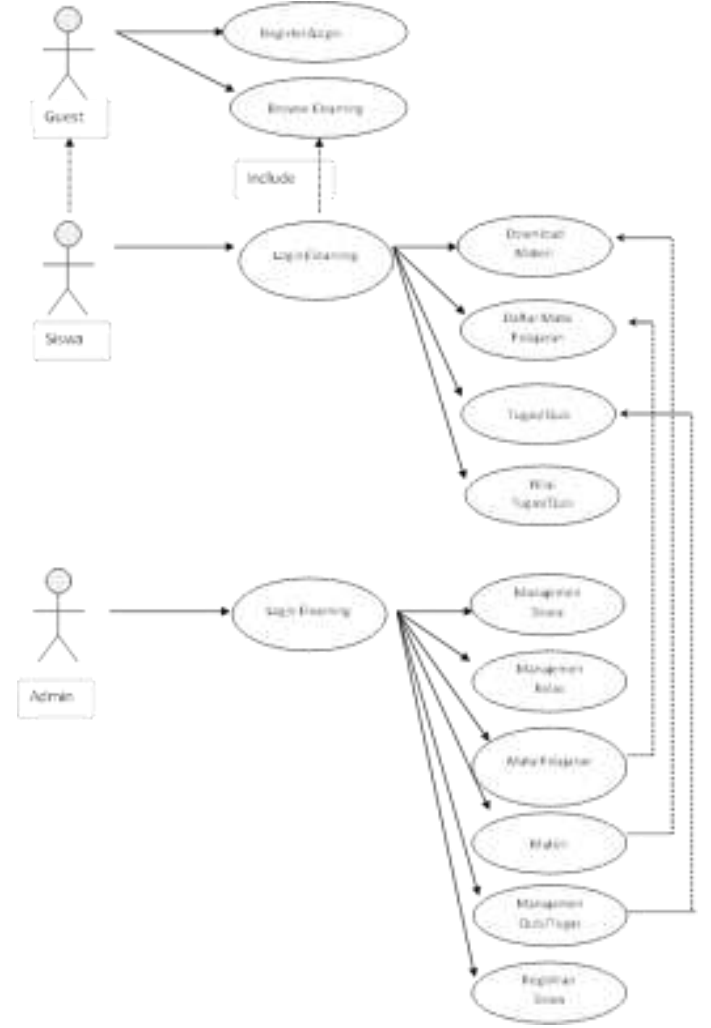

Gambar 19 Use Case E-Learning

\section{Acitivy Diagram}

Menggambarkan alur kerja (workflow) dari sistem yang diusulkan befokus kepada aktifitas yang dilakukan aktor dan sistem sehingga dapat dilihat gambaran jelas mengenai apa yang dilakukan aktor dan apa yang dilakukan sistem.

1. Acitivity diagram login administrator web

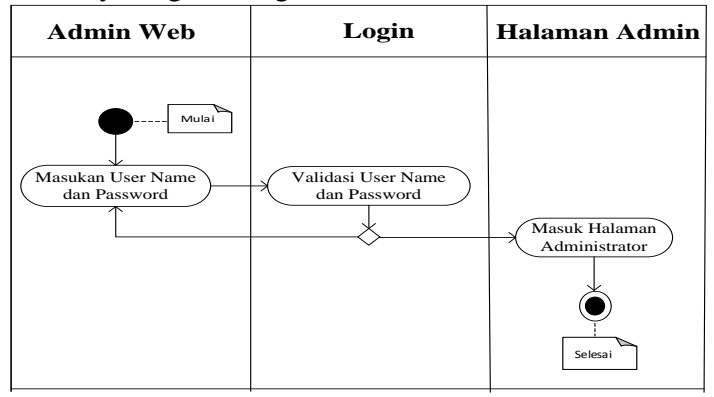

Gambar 20 Acitivy Diagram Admin

2. Acitivity diagram Register User

\begin{tabular}{|c|c|c|c|}
\hline User & Daftar User & Database & Tampil Data User \\
\hline & & \\
\hline
\end{tabular}

Gambar 21 Acitivy Diagram Register User

\section{Acitivy Diagram Home}

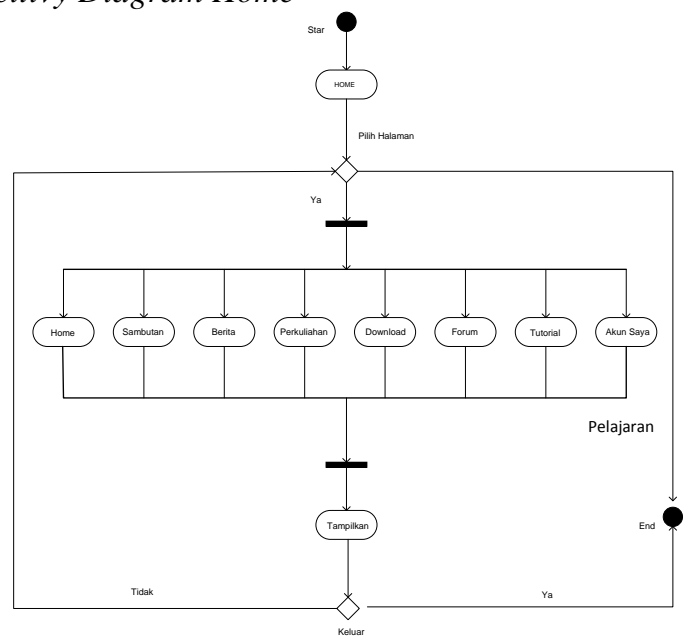

Gambar 22 Acitivy Diagram Home

4. Acitivy Diagram User

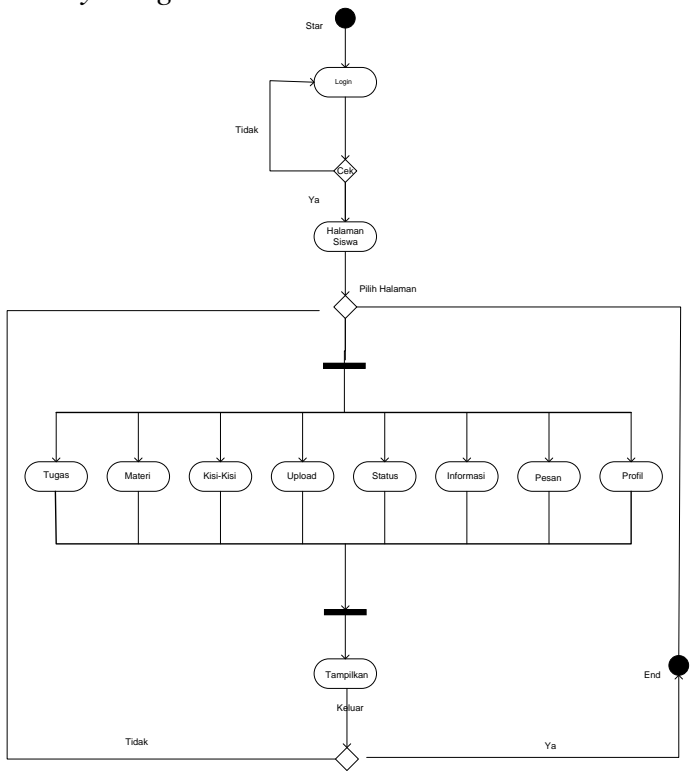

Gambar 23 Acitivy Diagram User

\section{Squence Diagram}

Sebuah diagram menunjukkan urutan interaksi object yang disusun dalam urutan waktu. Ini menggambarkan object dan class-class yang terlibat dalam skenario dan urutan pesan yang dipertukarkan antara object yang dibutuhkan untuk melaksanakan fungsi skenario. Kegunaannya untuk menunjukkan rangkaian pesan yang dikirim antara object juga interaksi antara object, sesuatu yang terjadi pada titik tertentu dalam eksekusi sistem. Komponen utama sequence diagram terdiri atas object yang dituliskan dengan kotak segi empat bernama pesan diwakili oleh garis dengan tanda panah dan waktu yang ditunjukkan dengan proses vertikal.

1. Sequence Diagram Admin 


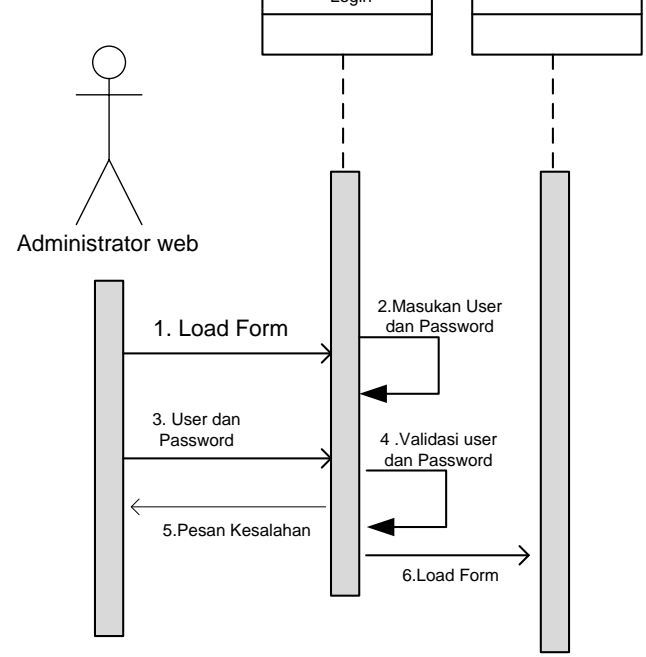

Gambar 24 Sequence Diagram login administrator web

\section{Sequence Diagram User}

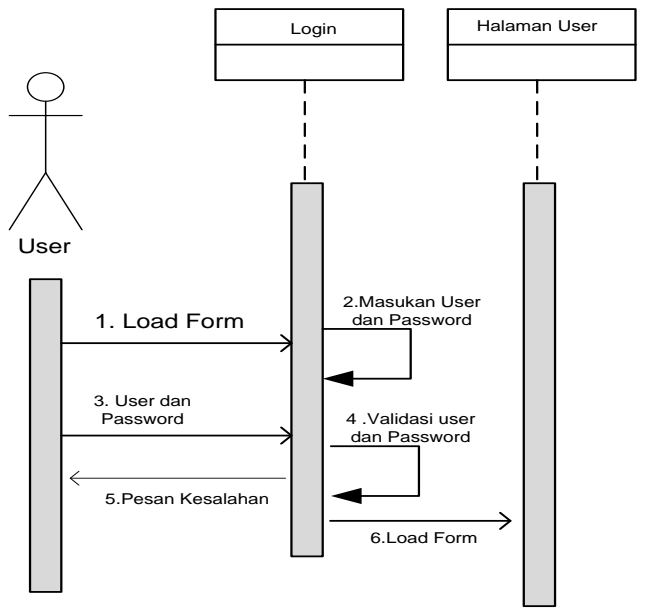

Gambar 25 Sequence Diagram User

3. Sequence Diagram Kisi-Kisi

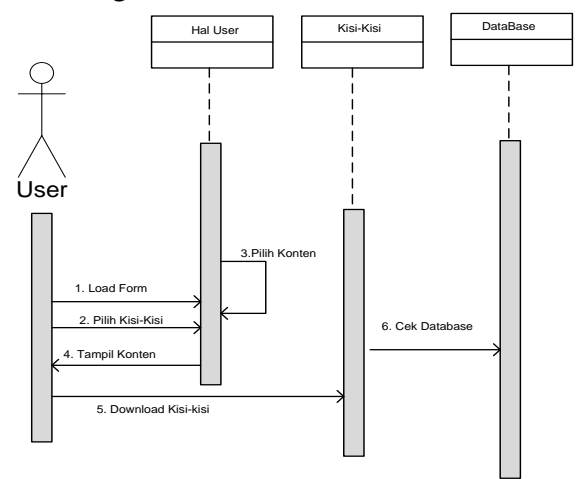

Gambar 26 Sequence Diagram Kisi-Kisi

4. Sequence Diagram Materi

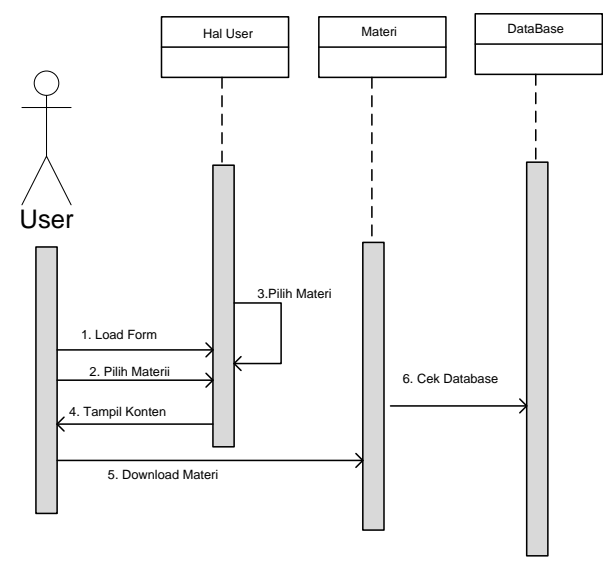

Gambar 27 Sequence Diagram Materi

5. Sequence Diagram Tugas

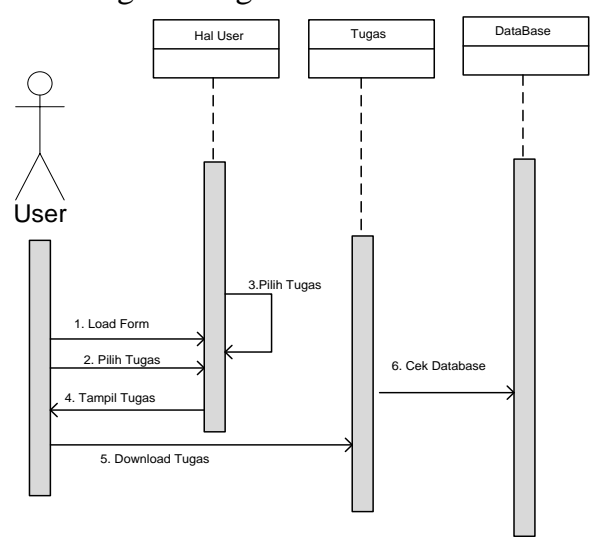

Gambar 28 Sequence Diagram Tugas

\section{KESIMPULAN DAN SARAN}

Berdasarkan data yang diperoleh dari hasil analisis yang dilakukan maka

dapat ditarik kesimpulan sebagai berikut:

1. Dengan adanya web server jaringan komputer di SMA Negeri 1 Baros maka jaringan lebih bermanfaat digunakan sebagai media pembelajaran, sehingga siswa dapat mengakses, mengunduh materi dan mengerjakan soal secara online.

2. Dengan adanya penerapan web server manggunakan debian linux ini dapat memanfaatkan PC dengan hardware minimum yang ada di SMA Negeri 1 Baros. Dengan hal ini tentu sangat menghemat anggaran dana dengan memanfaatkan barang yang sudah ada. Bahkan untuk PC yang tidak memiliki harddisk atau harddisknya rusak masih bisa digunakan. 


\section{REFERENCES}

[1] Andi (2009). Membangun Sistem Jaringan Komputer. Yogyakarta: Andi.

[2] Ashari, A. dkk. (2010). Linux Sistem Administrator Informatika. Bandung.

[3] Azikin, A. (2011). Debian Informatika. Bandung.

[4] Khairil, dkk. (2013). Membangun Web Server Intranet dengan Linux (Studi Kasus di Laboratorium Komputer SMP Negeri 38 Seluma Bengkulu Selatan), “Jurnal Media Infotama". Bengkulu.

[5] Lukas, J. (2006). Jaringan Komputer, Graha Ilmu, Jakarta.

[6] Mutaqin A, dkk. (2014). Web Server Embedded System. "Jurnal Teknologi Informasi dan Ilmu Komputer (JTIIK)”. Yogyakarta.

[7] Pradana. dkk. (2008). "DNS, Web Server dan Mail Server." Naskah Publikasi. Semarang: Teknik Elektro Universitas Negeri Diponegoro.
[8] Purbo OW, dkk. (2000). Membangun Server Internet dengan Free BSD. Andi. Yogyakarta.

[9] Ricky E, dkk. (2010). Virtual Private Server (VPS) sebagai Alternatif Pengganti Dedicated Server. "Seminar on Intelligent Teknoloy and Its Applicationt". Surabaya.

[10] Satya, I.A. (2006). Mengenal dan Menggunakan Mikrotik Winbox Router Modem Berbasis PC (Windows Dan Linux). DATAKOM : Jakarta.

[11] Sofana I. (2006). Langkah Mudah Membangun jaringan komputer Server, Informatika. Bandung.

[12] Theddy R. M. (2008). Perancangan dan Implementasi Web Server Clustering dengan Skema Load Balance Menggunakan Linux Virtual Server Via NAT. "Jurnal Teknologi Informasi”. Yogyakarta.

[13] Wahana. (2001). Mari Mengenal Linux. Semarang: Wahana Komputer. 